\title{
Thickly Populated and Abundant Resources but Struggling with Development: The Case of Nigeria
}

\author{
S. Y. Ibrahim¹, Hadiza Mali Bukar² \\ ${ }^{1}$ Department of Public Administration, University of Maiduguri, Maiduguri, Nigeria \\ ${ }^{2}$ Department of Public Administration, Yobe State University, Damaturu, Nigeria \\ Email: ysaalah@yahoo.com, hadizamalibukar22@gmail.com
}

How to cite this paper: Ibrahim, S. Y., \& Bukar, H. M. (2021). Thickly Populated and Abundant Resources but Struggling with Development: The Case of Nigeria. Theoretical Economics Letters, 11, 643-647. https://doi.org/10.4236/tel.2021.113042

Received: April 22, 2021

Accepted: June 26, 2021

Published: June 29, 2021

Copyright () 2021 by author(s) and Scientific Research Publishing Inc. This work is licensed under the Creative Commons Attribution International License (CC BY 4.0).

http://creativecommons.org/licenses/by/4.0/ (c) (i) Open Access

\begin{abstract}
The study focused on the subject matter of development. It attempted identifying reasons why a nation densely populated and blessed with abundant natural resources battle with development. The study depended on secondary data and historical description method used in data collection and analysis. Problems about religion, ethnicity and syndrome for getting rich quick are hampering any strategy for development in Nigeria. It is therefore recommended among others that the society must rise up to challenge any support for the quest to get rich quick syndrome so that corruption can be controlled or reduced being a dominant factor.
\end{abstract}

\section{Keywords}

Subject Matter of Development, Abundant Natural Resources, Economic Growth

\section{Introduction}

It has been observed that human resource constitutes the basis for the wealth of nations. Borrowed from the economists, human beings are agents who accumulate capital and exploit resources. After achieving that, the human being builds a socio-economic and political organization for the overall development of the nation. The issue of development has endured conceptual and methodological shift over the years (Akhakpe, 2014).

Various scholars gave their dispositions on the concept of development. For instance, Gboyega (2003) perceived it as an idea that embodies all attempts to improve the conditions of human existence in all ramifications. Naomi (1995) 
posits that development involves not only economic growth but some notion of equitable distribution of health care amenities and services, education, housing and other essential services with a view to promoting individual and collective equity of human life. But to (Akhakpe, 2014) development is a process of societal advancement where improvement in the well-being of the people is initiated through strong partnerships between all the sectors, corporate bodies and other groups in the society.

\section{Statement of the Problem}

Since its creation in 1914, several attempts have been made in order for Nigeria to develop and compete favourably among other nations of the world. Whenever such a move is made, it appears many set-backs develop to render such a plan ineffective. A nation thickly populated and endowed with natural resources, yet is grappling with development issue and consequently abandons the plan. It is against this background that this study examines the situation with a view to contributing positively to attainment of possible way of achieving development in Nigeria.

\section{Methodology}

The study depended on secondary data like journals, online publications, textbooks, web search etc. Historical descriptive method was used in data collection and analysis and consequently arriving at relevant conclusions.

\section{Conceptual Clarification}

The transformation of community into socially, economically, politically, educationally, orderly and materially to desirable conditions is referred to as development (Oye, 2014). From this perspective, development can be a process of bringing about a more equitable distribution of resources and income within the society. This sharply conforms with Akhakpe (2014) as stated in the introduction.

In their view, (Isiugo-Abanihe, 2002) quoted by Oye, development is not just a matter of getting more money into the hands of the poor, but ensuring that increased production and its resulting into improved standard of living. Thus, Onyeka (2010) contended that, a meaningful, concrete and lasting development begins and ends in the focus on human resources, that is, the supplier of labour and entrepreneurial function.

According to Ohagwu (2010) quoted by Oye (2014) development is not the same as change, growth or modernization, rather, its nature, content and course of a society. This view is in line with the disposition of Gboyega as mentioned in the introduction.

From the foregoing, development is not only getting more money into the hands of the poor, rather, ensure that such a move must increase production which will increase income and eventually improve living standard.

It has been argued that, for any meaningful, concrete and lasting development 
begins and ends in the focus on human resources (Oyenka, 2013). While the size of human resource depends on the population largely, the quality depends on educational, health services and environmental factors (i.e. an environment that promotes investment friendly platform). Paul et al. (2014) observed that, development is a composite process entailing socio-economic, political and cultural advancement of a nation. Therefore, from time to time, a nation must have a development agenda that it consciously pursues with both human and material resources it has. Paul therefore concluded that, national development is best achieved through development plan that encompasses the development strategies to be deployed for the purpose of development.

\section{Data Collection}

So far a number of strategies have been designed and adopted in Nigeria. However, it is not the intention of this paper to ex-ray, rather, will list some of them accordingly:

1) Community Boards-1954;

2) The Farm Settlement Scheme-1959;

3) The First National Development Plan-1962-1968;

4) The Second National Development Plan-1970-1974;

5) The Third National Development Plan-1975-1980;

6) The Fourth National Development Plan-1981-1985;

7) Economic Emergency Programme-1986;

8) Structural Adjustment Programme replaced the Economic Emergency Programme;

9) The various Rolling Plans;

10) Vision 2010;

11) Vision 20: 2020;

12) National Economic Empowerment and Development Strategy (NEEDS I \& II);

13) Millennium Development Goals;

14) The Seven-Point Agenda.

From the above list of development programmes, Nigeria has been involved in seeking for way out in terms of development. Each attempt had its predicament which cannot be discussed here.

\section{Data Analysis}

The general problems associated with poor performance include:

1) Lack of political will;

2) Inconsistency in policy and implementation;

3) Appropriate technology;

4) Corruption;

5) Top-down approach; 
6) Paucity of data;

7) Mis-management of resources;

8) Get rich quick syndrome.

a) Lack of political will: Those who are charged with the responsibility in most cases appear to think of themselves first. What they say is not what they do.

b) Inconsistency in policy and implementation: Some of the above mentioned policies came about as a result of inconsistency in policy and implementation, for example, Vision 2010 and the Seven-Point Agenda. If the content of the Vision 2010 to the later, certainly, there would not have been need for the Seven-Point Agenda.

c) Appropriate technology: In most cases, Nigeria embarks on importing sophisticated technology, very expensive, difficult to maintain due to cost and untrained personnel. Where such a technology is implemented it cannot be seen to the end and is abandoned.

d) Corruption: This is the fulcrum upon all others revolve. It appears to look like a cankerworm which defies all treatments. However, of late, a degree of fear has been injected into the system now.

e) Top-down approach: Most if not all the forementioned strategies, appeared to be top-down. This approach excludes the target beneficiaries. The resultant effect is that it ends up not meeting the needs of the people.

f) Mis-management of resources: Very often, the country depends on oil largely as from the 1970s. So much was obtained but the ability to manage it for efficient utilization became a problem. In fact, at a point, a former Head of State once said, "Money is not Nigeria's problem but how to spend it". A lot of gigantic projects have been embarked upon with little or no impact on the citizenry. The oil market now fluctuates and whenever, it is lower, countries like Nigeria suffers. The little that comes in as revenue is siphoned by those given responsibility of managing it.

g) Paucity of data: Effective planning depends on availability of data. In Nigeria, accurate data is a scarce commodity because, the government institution charged with the responsibility of generating the data is faced with some inadequacies coupled with the unwillingness of the people to reveal information and the outright manipulations of data for other gains. Therefore it is difficult if not impossible to have a good plan for the country.

h) Get rich quick syndrome: The population also contributed to the dilemma. It is now a "norm" in Nigeria that most people are eager to become rich. The society does not care about how people acquired their wealth. Instead of questioning, rather join to celebrate for amassing wealth. This act has positive correlation with the level of corruption characterizing the system. This has negative repercussions and can deter development. A nation thickly populated and is welcoming this altitude, why won't the nation be battling with development problems. 


\section{Conclusion}

The solution to the issues mentioned is not unsurmountable. What is required now is every individual must hold the nation at heart to protect the country being pulled back any development strategy put in place. Similarly, religious and ethnic differences must be stopped and ranks closed which will lead to serious continuity. Society must rise up to challenge the support for the quest for get rich quick syndrome. This will reduce the level of corruption in the system.

It is the hope of the authors that if the above are put in place, efficient and effective management of both the human and material resources of the country can be harnessed for meaningful and sustainable development.

\section{Conflicts of Interest}

The authors declare no conflicts of interest regarding the publication of this paper.

\section{References}

Akhakpe, I. P. (2014). Bureaucracy and Good Governance. Lagos: Pumark Nigeria Ltd.

Gboyega, A. (2003). Democracy and Development: The Imperative of Local Government. An Inaugural Lecture, Ibadan: University of Ibadan.

Isiugo-Abanihe, U. C. (2002). Quantitative Research Techniques. In Currents and Perspectivesin Sociology. In U. C. Usiugo-Abanihe, A. N. Isamah, \& J.O. Adesina (Eds.), Book's Name (Chapter 2, pp. 52-72). Ibadan: Malthouse Press.

Naomi, O. (1995). Towards an Integrated View of Human Rights. Hunger Teach Wet, 6, No. 3.

Ohagwu, C. A. (2010). Rural Development in Nigeria: Issues, Concepts and Practice. Enugu: John Jacoob’s Classic Publishers.

Onyeka, U. R. (2010). Development and Utilization of Human Resources of Rural Communities for Economic Growth. Journal of Sustainable Human Development Review, 2, No. 1 .

Oye, A. A. (2014). National Development Strategies: Challenges Options. International Journal of Humanities and Social Science Invention, 3, No. 4.

Oyenka, A. C. (2013). Dual to Ratio Estimators of Population Mean in Poststratified Sampling Using Known Value of Some Population Parameters. Global Journal of Science Frontier Research, 13, 13-23.

Paul, A., et al. (2014). The Cochaperone SGTA (Small Glutamine-Rich Tetratricopeptide repeat-Containing Protein Alpha) Demonstrates Regulatory Specificity for the Androgen, Glucocorticoid, and Progesterone Receptors. Journal of Biological Chemistry, 289, 15297-15308. https://doi.org/10.1074/jbc.M113.535229 